\title{
Effects of Vasoactive Chinese Herbs on the Endothelial NO System
}

\author{
Huige Li \\ Department of Pharmacology, University Medical Center, \\ Johannes Gutenberg University, Mainz,
}

Germany

\section{Introduction}

In the vasculature, nitric oxide (NO) is produced from the endothelium mainly by endothelial NO synthase (eNOS), which is activated by agonists such as bradykinin and acetylcholine or by shear stress produced by the flowing blood. NO is a potent vasodilator and protects blood vessels from thrombosis by inhibiting platelet aggregation and adhesion. In addition, endothelial NO possesses multiple anti-atherosclerotic properties, which include (i) prevention of leukocyte adhesion to the vascular endothelium and leukocyte migration into the vascular wall; (ii) decreased endothelial permeability, reduced influx of lipoproteins into the vascular wall and inhibition of low density lipoprotein (LDL) oxidation; and (iii) inhibition of DNA synthesis, mitogenesis, and proliferation of vascular smooth muscle cells [1, 2]. Recent studies suggest that eNOS is also involved in mitochondrial biogenesis, anti-aging effects and extension of lifespan in mammals [3, 4].

Based on the abovementioned protective effects of eNOS-derived NO, a pharmacological enhancement of NO production is of therapeutic interest. Indeed, numerous Chinese medicinal plants, herbal preparations, or isolated compounds thereof have been shown to stimulate endothelial NO production, which is likely to be a contributing mechanism for their therapeutic effects.

\section{Regulation of endothelial NO production}

Endothelial NO production is regulated at different levels, including

- Regulation of eNOS expression: expression of the eNOS enzyme is regulated at both the transcriptional and post-transcriptional levels. Estrogens, for example, increase eNOS expression by stimulating eNOS promoter activity. TNF $\alpha$, on the other hand, reduces eNOS expression by destabilizing eNOS mRNA [5, 6]. Several Chinese herbal products have been shown to enhance eNOS expression (Table 1).

- Regulation of eNOS activity by post-translational modifications: the enzymatic activity of eNOS is regulated by different cellular events such as increased intracellular $\mathrm{Ca}^{2+}$, interactions with substrates, co-factors, adaptors and regulatory proteins, and through shuttling between distinct subcellular domains [7]. In addition, eNOS activity is also regulated by post-translational modification of the eNOS protein. For example, phosphorylation of serine 1177 enhances eNOS activity, whereas phosphorylation of 
threonine 495 decreases eNOS activity [7]. Recent studies indicate that eNOS activity can be also enhanced by SIRT1-mediated deacetylation of lysine residues in the calmodulin-binding domain [8].

- Regulation of eNOS activity by changing the intracellular concentration of asymmetric dimethylarginine (ADMA): elevated plasma levels of ADMA have been shown to be associated with cardiovascular events and mortality. ADMA is believed to be an endogenous eNOS inhibitor, although NO-independent effects of ADMA have also been reported [9]. ADMA is formed during proteolysis and is degraded by the intracellular enzyme dimethylarginine dimethylaminohydrolase (DDAH). Decreased DDAH expression/activity is evident in disease states associated with endothelial dysfunction [10].

- Regulation of eNOS functionality: under a number of pathological conditions, the enzymatic reduction of molecular oxygen by eNOS is no longer coupled to L-arginine oxidation, resulting in production of superoxide rather than NO. This phenomenon is referred to as "eNOS uncoupling" [1,5]. A number of potential mechanisms have been reported to contribute to eNOS uncoupling. Among all of these mechanisms, a deficiency of the NOS cofactor tetrahydrobiopterin $\left(\mathrm{BH}_{4}\right)$ seems to be the primary cause

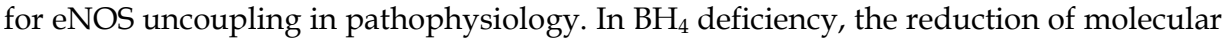
oxygen still occurs at the heme site of eNOS, but oxidation of the guanidine nitrogen of L-arginine is prevented, so that the reduced oxygen comes off the enzyme as superoxide [11, 12]. eNOS-mediated superoxide production has been observed in animal models of atherosclerosis, hypertension, diabetes mellitus and nitroglycerin tolerance, and also in patients with endothelial dysfunction resulting from hypercholesterolemia, diabetes mellitus, or essential hypertension, in chronic smokers, and in nitroglycerin-treated patients $[11,12]$. Thus, eNOS uncoupling turns eNOS from a NO-producing protective enzyme into a superoxide-generating deleterious molecule. It is therefore of therapeutic interest to reverse eNOS uncoupling and restore eNOS functionality. An elevation of endothelial $\mathrm{BH}_{4}$ levels (by enhancing $\mathrm{BH}_{4}$ biosynthesis and/or by preventing oxidative stress-mediated $\mathrm{BH}_{4}$ oxidation) may reverse eNOS uncoupling [13]. Chinese herbs containing large amounts of polyphenolic compounds with antioxidant properties may have the potential to prevent $\mathrm{BH}_{4}$ oxidation and eNOS uncoupling.

- $\quad$ Regulation of NO bioactivity by reducing the levels of reactive oxygen species (ROS): $\mathrm{NO}$ can be rapidly inactivated by superoxide. A reduction of oxidative stress (by downregulating ROS-producing enzymes, upregulating antioxidant enzymes, or by ROS scavenging activities) may enhance NO bioactivity by two means: prevention of eNOS uncoupling and reduction of superoxide-mediated NO inactivation [1].

\section{Searching for eNOS-enhancing Chinese herbs}

Numerous Chinese herbs have been shown to enhance endothelial NO production. These reports are summarized in Table 1. This chapter focuses on our own findings.

EA.hy 926 cells are an immortalized endothelial cell line derived from human umbilical vein endothelial cells (HUVEC). This cell line has been generated by fusing HUVEC with the permanent human alveolar epithelial cell line A549 [14]. We cloned the 5'-flanking region (3.5 $\mathrm{kb}$ in length) of the human eNOS gene into $\mathrm{pGL}_{3}-\mathrm{neo}$, which contains a promoterless 
luciferase reporter gene and a neomycin resistance gene [15]. Stable transfection of EA.hy 926 cells with this construct (selection using G418) resulted in an immortalized human endothelial cell line (termed "stable EA.hy cells" for simplicity) that expresses the luciferase gene driven by the human eNOS promoter. Luciferase activity in cell homogenates, which can be easily measured in a luminometer or on a chemiluminescence plate reader, is used as a determinant of promoter activity of the human eNOS gene.

To search for eNOS-regulating Chinese herbs, we generated aqueous extracts of 17 herbs possessing "circulation-improving" effects according to traditional Chinese medicine (TCM) [16]. These were:

- Angelicae sinensis radix

- Astragali radix

- Carthami flos

- Celosiae semen

- Chrysanthemi indici flos

- Eucommiae cortex

- $\quad$ Ligustici radix

- Metaphyreum roseum

- Moutan radicis cortex

- Paeoniae rubrae radix

- Panacis notoginseng radix

- Persicae semen

- Prunella vulgaris L.

- Puerariae radix

- Salviae miltiorrhizae radix

- Uncariae ramulus et unci

- Zizyphi spinosae semen

Human EA.hy 926 endothelial cells stably transfected with a $3.5 \mathrm{~kb}$ fragment of the human eNOS promoter (stable EA.hy cells) were treated with each extract (corresponding to $5 \mathrm{~g}$ of raw plant extract per $\mathrm{ml}$ ) at dilutions of 1:100000 to 1:300 for 18 hours to study their effects on eNOS promoter activity. Ten herbal extracts increased eNOS promoter activity in a concentration-dependent manner with a maximal effect over 150\%: Carthami flos, Chrysanthemi indici flos, Eucommiae cortex, Ligustici radix, Paeoniae rubrae radix, Prunella vulgaris L., Puerariae radix, Uncariae ramulus et unci, Salviae miltiorrhizae radix and Zizyphi spinosae semen.

These ten herbal extracts were further analyzed in a second screening (RNase protection assay) for their effect on eNOS mRNA levels in normal EA.hy 926 cells. In this experiment, only Prunella vulgaris L., Salviae miltiorrhizae radix and Zizyphi spinosae semen significantly increased eNOS mRNA expression [16].

Our screening procedure using stable EA.hy cells has some limitations: (i) it is based on eNOS promoter activity and the positive results must be verified by additional methods for analyses of mRNA expression to exclude false positive hits. (ii) Herbs/compounds that regulate NO production via mechanisms other than modulating eNOS expression will provide false negative results. For example, Astragali radix had no effect on eNOS expression and was negative in our screening. However, Astragali radix can stimulate NO production from eNOS by enhancing eNOS enzymatic activity [17]. Despite of its limitations, this screening procedure has the advantages of being a low-cost method of relatively high 
efficiency which is easy to perform. Because of these strengths, it has also been used by pharmaceutical companies in the screening for eNOS enhancers [18]. Based on this screening, we have identified Prunella vulgaris L., Salviae miltiorrhizae radix and Zizyphi spinosae semen as eNOS-regulating Chinese herbs.

\begin{tabular}{|c|c|c|c|c|c|}
\hline Plant & \begin{tabular}{|l|} 
Compounds / \\
extracts
\end{tabular} & Cells / models & Effects on eNOS & Additional effects & References \\
\hline Astragali radix & extract & HUVEC & eNOS activity $\uparrow$ & $\begin{array}{l}\text { VEGF } \uparrow, P I 3 K-A k t \uparrow, \\
\text { angiogenesis } \uparrow\end{array}$ & [17] \\
\hline Epimedii herba & icariin & $\begin{array}{l}\text { coronary artery } \\
\text { isolated from } \\
\text { canine }\end{array}$ & eNOS activity $\uparrow$ & vasodilation & {$[74]$} \\
\hline Ginseng & ginsenosides & $\begin{array}{l}\text { I/R in } \\
\text { Langendorff } \\
\text { hearts; HAEC }\end{array}$ & eNOS-P $\uparrow$ & $\begin{array}{l}\text { cardiac function } \uparrow, \\
\text { coronary perfusion } \\
\text { flow } \uparrow, \text { prostacyclin } \uparrow, \\
\text { PI3K-Akt } \uparrow\end{array}$ & [75] \\
\hline \begin{tabular}{|l} 
Ginseng \\
(Korean red \\
ginseng)
\end{tabular} & $\begin{array}{l}\text { saponin } \\
\text { fraction }\end{array}$ & Hypertensive rats & eNOS activity $\uparrow$ & blood pressure $\downarrow$ & {$[76]$} \\
\hline $\begin{array}{l}\text { Magnolia } \\
\text { officinalis }\end{array}$ & honokiol & $\begin{array}{l}\text { oxLDL-treated } \\
\text { HUVEC }\end{array}$ & $\begin{array}{l}\text { eNOS protein } \\
\text { expression } \uparrow\end{array}$ & $\begin{array}{l}\text { adhesion molecules } \downarrow \text {, } \\
\text { EC-monocyte } \\
\text { interaction } \downarrow \text {, } \\
\text { LDL-oxidation } \downarrow \text {, } \\
\text { ROS } \downarrow\end{array}$ & [77] \\
\hline \begin{tabular}{|l|} 
Panax \\
notoginseng
\end{tabular} & saponin extract & $\begin{array}{l}\text { HUVEC / } \\
\text { zebrafish }\end{array}$ & eNOS-P $\uparrow$ & $\begin{array}{l}\text { angiogenesis } \uparrow, \\
\text { VEGF } \uparrow, \text { PI3K-Akt } \uparrow\end{array}$ & [78] \\
\hline $\begin{array}{l}\text { Polygonum } \\
\text { multiflorum }\end{array}$ & TSG & $\begin{array}{l}\text { aorta isolated } \\
\text { from fat-fed rats }\end{array}$ & $\begin{array}{l}\text { eNOS } \\
\text { expression } \uparrow\end{array}$ & $\begin{array}{l}\text { endothelial function } \uparrow \\
\text { intimal remodeling } \downarrow \text {, } \\
\text { iNOS } \downarrow\end{array}$ & [79] \\
\hline $\begin{array}{l}\text { Pueraria } \\
\text { lobata }\end{array}$ & puerarin & fat-fed rats & \begin{tabular}{|l} 
eNOS \\
expression $\uparrow$
\end{tabular} & cholesterol $\downarrow$ & [80] \\
\hline $\begin{array}{l}\text { Prunella } \\
\text { vulgaris }\end{array}$ & extract & EA.hy / HUVEC & \begin{tabular}{|l|} 
eNOS \\
expression $\uparrow$
\end{tabular} & $\mathrm{NO}^{\uparrow}$ & [16] \\
\hline \multirow{6}{*}{$\begin{array}{l}\text { Salvia } \\
\text { miltiorrhiza } \\
\text { (Danshen) }\end{array}$} & \begin{tabular}{|l|} 
crypto- \\
tanshinone
\end{tabular} & HUVEC & \begin{tabular}{|l} 
eNOS \\
expression $\uparrow$
\end{tabular} & ET- $\downarrow \downarrow$, NF-кB $\downarrow$ & [81] \\
\hline & \begin{tabular}{|l} 
magnesium \\
lithospermate \\
B
\end{tabular} & \begin{tabular}{|l|} 
HUVEC \\
(hyperglycemia) / \\
OLETF rats
\end{tabular} & eNOS-P $\uparrow$ & $\begin{array}{l}\text { Endothelial function } \uparrow \\
\text { Akt } \uparrow, N r f-2 \uparrow, H O-1 \uparrow\end{array}$ & {$[82]$} \\
\hline & \begin{tabular}{|l|} 
tanshinone IIA \\
\end{tabular} & $\begin{array}{l}\text { angiotensin II- } \\
\text { treated rat cardiac } \\
\text { fibroblasts }\end{array}$ & eNOS-P $\uparrow$ & $\begin{array}{l}\text { ET-1 } \downarrow, \text { ROS } \downarrow \text {, } \\
\text { fibroblast } \\
\text { proliferation } \downarrow\end{array}$ & [83] \\
\hline & tanshinone IIA & $\begin{array}{l}\text { renovascular } \\
\text { hypertension } \\
\text { model in hamsters }\end{array}$ & $\begin{array}{l}\text { eNOS } \\
\text { expression } \uparrow \\
\text { eNOS -P } \uparrow\end{array}$ & $\begin{array}{l}\text { Vasodilation, } \\
\text { blood pressure } \downarrow\end{array}$ & [84] \\
\hline & \begin{tabular}{|l} 
extract / \\
ursolic acid
\end{tabular} & \begin{tabular}{|l|} 
EA.hy 926 / \\
HUVEC
\end{tabular} & $\begin{array}{l}\text { eNOS } \\
\text { expression } \uparrow\end{array}$ & NADPH oxidase $\downarrow$ & {$[24]$} \\
\hline & extract & \begin{tabular}{|l} 
rat hypoxic \\
pulmonary \\
hypertension
\end{tabular} & \begin{tabular}{|l|} 
eNOS \\
expression $\uparrow$
\end{tabular} & $\begin{array}{l}\text { media thickening } \downarrow \text {, } \\
\text { iNOS } \downarrow\end{array}$ & [85] \\
\hline Seabuckthorn & flavonoids & EA.hy 926 & $\begin{array}{l}\text { eNOS } \\
\text { expression } \uparrow\end{array}$ & LOX-1 $\downarrow$, cell death $\downarrow$ & [86] \\
\hline
\end{tabular}




\begin{tabular}{|c|c|c|c|c|c|}
\hline Plant & $\begin{array}{l}\text { Compounds / } \\
\text { extracts }\end{array}$ & Cells / models & Effects on eNOS & Additional effects & References \\
\hline $\begin{array}{l}\text { Sophora } \\
\text { flavescens roots }\end{array}$ & matrine & RIMEC & $\begin{array}{l}\text { eNOS } \\
\text { expression } \uparrow\end{array}$ & $\begin{array}{l}\text { IL-6, IL-8 \& sICAM- } \\
1 \downarrow\end{array}$ & {$[87]$} \\
\hline $\begin{array}{l}\text { Szechwan } \\
\text { lovage rhizome }\end{array}$ & TMP & $\begin{array}{l}\text { Cerebral } \\
\text { vasospasm in } \\
\text { rabbit }\end{array}$ & $\begin{array}{l}\text { eNOS } \\
\text { expression } \uparrow\end{array}$ & cerebral vasospasm $\downarrow$ & {$[88]$} \\
\hline $\begin{array}{l}\text { Xanthoceras } \\
\text { sorbifolia }\end{array}$ & ethanol extract & Rat aorta & eNOS activity $\uparrow$ & vasodilation & {$[89]$} \\
\hline $\begin{array}{l}\text { Zizyphi Spinosi } \\
\text { semen }\end{array}$ & betulinic acid & EA.hy / HUVEC & $\begin{array}{l}\text { eNOS } \\
\text { expression } \uparrow\end{array}$ & ROS $\downarrow$ & {$[62]$} \\
\hline \multicolumn{6}{|c|}{ Combinations \& compounds } \\
\hline A\&A & decoction & $\begin{array}{l}\text { obstructed rat } \\
\text { kidney }\end{array}$ & eNOS activity $\uparrow$ & renal fibrosis $\downarrow$, ROS $\downarrow$ & {$[90]$} \\
\hline ELCAS & extract & $\begin{array}{l}\mathrm{H}_{2} \mathrm{O}_{2} \text {-treated } \\
\text { ECV304 }\end{array}$ & $\begin{array}{l}\text { eNOS } \\
\text { expression } \uparrow\end{array}$ & $\mathrm{SOD} \uparrow, \mathrm{CAT} \uparrow, \mathrm{GPx} \uparrow$ & {$[91]$} \\
\hline $\begin{array}{l}\text { Qing Huo Yi } \\
\text { Hao }\end{array}$ & TMP & $\begin{array}{l}\text { glucose-treated } \\
\text { bEnd.3 }\end{array}$ & $\mathrm{eNOS-P} \uparrow$ & ROS $\downarrow, \mathrm{Akt} \uparrow, \mathrm{UCP} 2 \uparrow$ & {$[92]$} \\
\hline $\begin{array}{l}\text { Refined Qing } \\
\text { Kai Ling }\end{array}$ & injection & MCAO in rats & $\begin{array}{l}\text { eNOS } \\
\text { expression } \uparrow\end{array}$ & infarct size $\downarrow$ & [93] \\
\hline Shen-fu & injection & $\begin{array}{l}\text { myocardial I/R in } \\
\text { diabetic rats }\end{array}$ & $\mathrm{eNOS-P} \uparrow$ & infarct size $\downarrow$, Akt $\uparrow$ & {$[94]$} \\
\hline \multirow[t]{2}{*}{ Tongxinluo } & \multirow[t]{2}{*}{ compound } & $\begin{array}{l}\text { HUVEC / aortic } \\
\text { rings from rats on } \\
\text { a methionine-rich } \\
\text { diet }\end{array}$ & $\begin{array}{l}\text { eNOS } \\
\text { expression } \uparrow\end{array}$ & $\begin{array}{l}\text { Endothelial } \\
\text { function } \uparrow, \\
\text { PI3K-Akt } \uparrow\end{array}$ & [95] \\
\hline & & $\begin{array}{l}\text { myocardial no- } \\
\text { reflow and I/R in } \\
\text { minipigs }\end{array}$ & $\mathrm{eNOS-P} \uparrow$ & PKA $\uparrow$, infarct size $\downarrow$ & {$[96]$} \\
\hline
\end{tabular}

A\&A, a combination of roots Astragalus membranaceus var. mongholicus and Angelica sinensis; bEnd.3, mouse brain microvascular cells; CAT, catalase; EA.hy 926, an immortalized human endothelial cell line derived from HUVEC; ECV 304, a misidentified (as endothelial cells) human bladder cell line of epithelial origin; ELCAS, an extract of Ligusticum chuanxiong and Angelica sinensis; eNOS-P, eNOS phosphorylation at serine 1177; GPx, glutathione peroxidase; HAEC, human aortic endothelial cells; HO-1, heme oxygenase-1; H/R, hypoxia/reoxygenation; HUVEC, human umbilical vein endothelial cells; $\mathrm{I} / \mathrm{R}$, ischemia-reperfusion injury; $\mathrm{MCAO}$, middle cerebral artery occlusion; Nrf-2, nuclear factor erythroid 2-related factor-2; OLETF, Otsuka Long-Evans Tokushima Fatty rats; RIMEC, rat intestinal microvascular endothelial cells; ROS, reactive oxygen species; SOD, superoxide dismutase; TMP, tetramethylpyrazine; TSG, 2,3,4',5-tetrahydroxystilbene 2-O-beta-D-glucoside; UCP2, uncoupling protein 2.

Table 1. Effects of Chinese herbs on endothelial NO production.

\subsection{Prunella vulgaris L. (PVL)}

PVL is used in TCM as well as in Western herbal medicine. In the West, the plant has been used primarily as a remedy to alleviate pains in the throat, to treat fevers and to accelerate wound healing. Modern pharmacological studies have revealed a wide array of biological effects and numerous therapeutic possibilities for the herb, including anti-viral and antibacterial effects, immunomodulatory, anti-allergy and anti-cancer potential, as well as antioxidant activity [16]. 
In TCM, PVL (fruiting spikes) is used as an anti-microbial, anti-inflammatory and antitumor drug [19], but it is also commonly used as a component in combination therapy for hypertension.

PVL extracts relax isolated epinephrine-precontracted rabbit aorta [20]. Intravenous injection of PVL saponins results in a reduction of both systolic and diastolic blood pressures in anesthetized rats [21]. A PVL-containing Chinese herb combination (consisting of Crataegus pinnatifida Bge, Uncariae ramulus et uncis, Alisma orientalis radix and PVL at 1:1:1:1, w/w) reduces blood pressure and lowers cholesterol and triglyceride in hypertensive and hypercholesterolemic patients [22].

Our study demonstrated that PVL is an effective eNOS-upregulating herb; it significantly increases eNOS promoter activity, eNOS mRNA and protein expression and NO production in human endothelial cells [16].

PVL extracts contain a variety of chemical constituents, including triterpenoids (such as ursolic acid, betulinic acid, oleanolic acid, vulgarsaponins), steroids (such as $\beta$-sitosterol, stigmasterol, $\alpha$-spinasterol), flavonoids (such as rosmarinic acid, luteolin, cynaroside, homoorientin, quercetin), coumarins (such as umbelliferone, scopoletin, esculetin), organic acids (such as caffeic acid, palmitic acid, stearic acid, oleic acid, arachidic acid, lauric acid, myristic acid), sugars, as well as essential oils [23].

Importantly, our studies have demonstrated that ursolic acid (also present in Salviae miltiorrhizae radix) [24], betulinic acid (also a constituent of Zizyphi spinosae semen) [24], luteolin and cynaroside (also constituents of artichoke, Cynara scolymus L.) [25] are eNOSupregulating compounds. Ursolic acid and betulinic acid are two of the main PVL triterpenoids; luteolin and cynaroside are two of the main PVL flavonoids [23]. Therefore, these four compounds, possibly in combination with other yet unidentified compounds, may be responsible for the observed eNOS-upregulating effect of PVL.

Our recent experience indicates that the effects of PVL on eNOS may vary significantly from batch to batch. With the last two batches of PVL products we bought recently, we could not find any eNOS-enhancing activities. This might be due to concentration variation of the active constituents in the PVL plant.

\subsection{Salviae miltiorrhizae radix (Danshen)}

Danshen, the dried root of Salvia miltiorrhiza Bunge (Lamiaceae), is one of the most commonly used TCM remedies. A Danshen-containing preparation was the first TCM product approved for phase II and III clinical trials by the Food and Drug Administration (FDA) [26]. Ancient TCM books describe Danshen as a drug "improving circulation" and "removing blood stasis". Today, Danshen is available in China, Japan, the United States, and also in many European countries and is used for the treatment of angina pectoris, hyperlipidemia, and acute ischemic stroke [26]. Clinical trials have indicated that Danshen preparations are superior to nitroglycerin or isosorbide dinitrate for the treatment of stable angina pectoris, with respect to efficacy and side effects [27, 28].

Various in vitro and in vivo studies have demonstrated that several constituents of Danshen can improve microcirculation, dilate coronary arteries, increase blood flow, and prevent myocardial ischemia. Aqueous Danshen extracts and purified active principles of Danshen (tanshinones) have been shown to cause vasodilation of coronary, renal, femoral, and mesenteric arteries, and suppress systemic blood pressure in rats and rabbits $[29,30]$. In a rat acute myocardial infarction model, Danshen extracts increased the survival rate and 
reduced the infarct size to an extent comparable with that of the angiotensin converting enzyme inhibitor ramipril [31]. Tanshinone IIA, a pharmacologically active component isolated from Danshen, reduced myocardial infarct size by about $50 \%$ in a rabbit ischemiareperfusion model [32].

Interestingly, the cardiovascular protective effects of Danshen resemble the action profile of endothelium-derived NO. Danshen extracts and constituents inhibit platelet aggregation [33] and attenuate neutrophil-endothelial adhesion [34]. Danshen also lowers plasma cholesterol levels, enhances smooth muscle apoptosis and attenuates neointimal hyperplasia in the balloon-injured abdominal aorta of hypercholesterolemic rabbits [35]. Danshen has also been shown to reduce lipid peroxidation, inhibit LDL oxidation, and reduce atherosclerosis in cholesterol-fed rabbits [36].

In stable EA.hy cells we have identified Danshen as an eNOS-enhancer. Danshen extracts increase eNOS promoter activity, eNOS mRNA and protein expression, as well as endothelial NO production [24]. Danshen extracts contain large amounts of polyphenolic compounds with antioxidant properties $[26,37]$. This may prevent $\mathrm{BH}_{4}$ oxidation and eNOS uncoupling.

So far, more than 100 compounds have been isolated and identified from Danshen. Most of the lipophilic compounds are diterpene chinone compounds of the tanshinone type, including tanshinone I, IIA, and IIB, cryptotanshinone, dihydrotanshinone, and other related compounds [26, 37]. Hydrophilic constituents include polyphenolic acids (such as various salvianolic acids) and related compounds (such as danshensu, i.e. salvianic acid A, protocatechuic aldehyde, and protocatechuic acid); but also rosmarinic acid and isoferulic acid. Baicalin and ursolic acid have been isolated from alcohol extracts of Danshen [26].

In EA.hy 926 cells, an aqueous extract of Danshen and a methanol extract of the plant increase eNOS promoter activity, eNOS mRNA and protein expression. On the contrary, a dichloromethane extract does not change eNOS gene expression [24]. Thus, hydrophilic and alcohol-soluble, but not lipophilic constituents of Danshen seem to be responsible for its eNOS-upregulating effect. Accordingly, the commercially available lipophilic compounds (tanshinone I, tanshinone IIA, cryptotanshinone and dihydrotanshinone) of Danshen have no effect on eNOS expression in EA.hy 926 cells [24]. We have also tested several commercially available hydrophilic compounds, including protocatechuic acid, protocatechuic aldehyde, rosmarinic acid, isoferulic acid, salvianic acid A, and salvianolic acid B. They show no significant effects on eNOS expression [24]. Therefore, the hydrophilic compounds that are responsible for the eNOS-upregulating effect of Danshen still remain to be identified. Among the alcohol-soluble compounds, we have found that ursolic acid, but not baicalin, significantly enhances eNOS mRNA and protein expression [24]. Therefore, ursolic acid is likely to represent one of the compounds responsible for enhanced eNOS expression in response to Danshen.

\subsection{Ursolic acid}

Ursolic acid is a secondary plant metabolite not only found in Danshen [38], but also widespread in some other plants including apple pomace, rosemary leaves, and sage leaves (Salvia officinalis) [39]. This pentacyclic triterpenoid has emerged as a multifunctional compound with diverse pharmacological properties, including anticancer, antioxidant, antiinflammatory, anti-HIV, antimicrobial, and hepatoprotective activities. Currently, ursolic acid is in human clinical trials for treating cancer and skin wrinkles [40, 41]. In addition, ursolic acid possesses anti-obestic and anti-diabetic effects. It prevents abdominal adiposity 
[42, 43], improves pancreatic beta-cell function [44], ameliorates glucose intolerance [45], inhibits hepatic glucose production in diabetic mice [46], and inhibits diabetic nephropathy $[47,48]$.

Also in the cardiovascular system, ursolic acid shows therapeutic effects. In rat models of hypertension, ursolic acid prevents the development of severe hypertension which may be attributed to a potent diuretic/saluretic activity and a negative chronotropic effect. In addition, ursolic acid shows antihyperlipidemic (reduction of LDL and triglycerides), antioxidant (upregulation of glutathione peroxidase, GPx, and superoxide dismutase, SOD), and hypoglycemic effects [49].

The reported effects of ursolic acid on atherogenesis are controversial. TNF $\alpha$-induced Eselectin expression is shown to be suppressed by ursolic acid via the inhibition of NF- $\mathrm{KB}$ [50]. In the rat carotid artery injury model, ursolic acid has been demonstrated to inhibit neointima formation [51]. In contrast, a recent study has shown that oral treatment of apolipoprotein E-knockout mice with ursolic acid for 24 weeks accelerates atherosclerotic plaque formation in a dose-dependent manner [52]. In the latter study, ursolic acid inhibited endothelial proliferation and induced endothelial cell death. Ursolic acid caused DNA damage, followed by the activation of a p53-, BAK-, and caspase-dependent cell-death pathway [52]. Further studies are needed to clarify this controversy.

We have provided the first evidence that ursolic acid enhances eNOS mRNA and protein expression in human endothelial cells [24]. This leads to increased NO production and improved endothelial cell function. In a recent study by Lee et al., treatment of human coronary artery endothelial cells with ursolic acid increased tube formation, endothelial cell migration capacities and the expression of allograft inflammatory factor-1 (AIF-1, a mediator of vasculogenesis) through an NO-related mechanism [53]. In a mouse hind limb ischemia model, ursolic acid enhanced eNOS and AIF-1 expression, and increased collateral blood flow and capillary density through the induction of neovascularization [53].

In addition to this stimulatory effect on gene expression observed at concentrations of 1-10 $\mu \mathrm{M}$, ursolic acid at higher concentrations also stimulated eNOS activity. In organ chamber experiments with isolated rat aorta, ursolic acid (and a methanolic extract of Lepechinia caulescens) induced an endothelium-dependent, $\mathrm{NO}$-mediated vasodilation $\left(\mathrm{EC}_{50}\right.$ for ursolic acid $44 \mu \mathrm{M})$ [54].

Ursolic acid also possesses anti-oxidative effects. It has been shown to reduce endothelial superoxide production by suppressing the expression of NOX4 [24], which is the predominant NADPH oxidase isoform in endothelial cells [55]. In addition, ursolic acid also enhances ROS inactivation by upregulating the expression/activity of antioxidant enzymes, e.g., GPx and SOD [49]. Thus, ursolic acid may also have the potential to prevent $\mathrm{BH}_{4}$ oxidation and eNOS uncoupling.

\subsection{Zizyphi spinosae semen (ZSS)}

ZSS is a sedative and hypnotic drug with additional effects on the cardiovascular system [19]. ZSS protects cardiomyocytes from ischemic injury, and oxygen and glucose deprivation-induced damage of cultured neonatal rat myocardial cells can be markedly reduced by ZSS total saponins [56]. Anoxia/reoxygenation of cultured neonatal rat myocardial cells results in increased intracellular malondialdehyde and lipid peroxides, increased intercellular calcium concentration and decreased SOD activity. All of these parameters can be reversed by ZSS total saponins [56, 57]. 
ZSS has also antihypertensive effects. Intravenous injection of an aqueous solution of ZSS extract markedly decreases blood pressure in anesthetized rats, dogs, and cats without any significant effect on coronary blood flow, heart rate, or myocardial contractility [58]. Oral treatment of spontaneously hypertensive rats with ZSS jujubosides resultes in a reduction in blood pressure [59]. Blood pressure reduction can be observed as early as $30 \mathrm{~min}$ and lasted for at least $3.5 \mathrm{~h}$; the effect declined after $7.5 \mathrm{~h}$ [59]. Moreover, treatment of hypercholesterolemic rabbits with ZSS for three months leads to a reduction in total cholesterol, LDL cholesterol and triglycerides, an increase in HDL and a decrease in atherosclerotic lesions [60].

The molecular mechanisms underlying these cardiovascular effects are poorly understood. Interestingly, treatment of rats with ZSS resulted in increased plasma levels of NO through unknown mechanisms [61]. We have found that ZSS increases eNOS promoter activity, eNOS mRNA and protein expression, as well as NO production in human endothelial cells [62].

The active constituents of ZSS include saponins, triterpenoids, flavonoids, alkaloids, and fatty acids $[19,63,64]$. The most important ZSS saponins are triterpenoid oligoglycosides, such as jujubosides A and B. Triterpenoids found in ZSS include betulin and betulinic acid $[63,65]$.

Jujuboside A, B and betulin show no effect on eNOS promoter activity or eNOS mRNA expression. Interestingly, treatment of human endothelial cells with betulinic acid results in a significant up-regulation of eNOS mRNA and protein expression [62]. The content of betulinic acid in ZSS is approximately $7 \mathrm{mg} / \mathrm{kg}$ [63]. When cells are treated with this ZSS extract (concentration of $5 \mathrm{~g} / \mathrm{ml}$ ) at a 1:100 dilution, the estimated final concentration of betulinic acid is in the low micromolar range. In our study, betulinic acid increases eNOS mRNA expression even at $1 \mu \mathrm{M}$. Thus, betulinic acid is likely to be one of the compounds responsible for the eNOS up-regulation induced by ZSS [62].

\subsection{Betulinic acid}

The pentacyclic triterpenoid betulinic acid is not only found in ZSS, but is also widespread in fruit peel, leaves and stem bark of several species of plants, including white birch bark (Betula pubescens), plane bark (Plantanus acerifolia), rosemary leaves (Rosmarinus officinalis), Ber tree (Ziziphus mauritiana) and selfheal (Prunella vulgaris) [39, 66]. The compound is mainly known for its anti-tumor, anti-viral and anti-inflammatory activities [66, 67]. Our study has identified betulinic acid as an eNOS-stimulating compound [62].

Interestingly, accumulating data in the recent years support a protective effect of betulinic acid in the cardiovascular system. In a rat renal ischemia/reperfusion (I/R) injury model, betulinic acid attenuates I/R-induced oxidant responses, inhibits microscopic damage, and improves renal function by regulating the apoptotic function of leukocytes and inhibiting neutrophil infiltration [68]. Recently, betulinic acid and ursolic acid have been identified as selective agonists of the G protein-coupled receptor TGR5, which plays an important role in the control of energy metabolism. This suggests the therapeutic potential of betulinic acid and ursolic acid for metabolic diseases [69].

In HUVEC, betulinic acid has been shown to inhibit TNF $\alpha$-induced ROS production and NF- $\kappa \mathrm{B}$ activation. The resulting inhibition of endothelial activation and leukocyte adhesion points to a protective role of the compound against vascular inflammation [70]. 
We have found that betulinic acid upregulates eNOS expression in endothelial cells [62]. As mentioned above, upregulation of eNOS does not necessarily result in an increase in bioactive NO. Under pathological conditions of oxidative stress, eNOS is often uncoupled and dysfunctional. The primary cause of eNOS uncoupling is a deficiency of its cofactor $\mathrm{BH}_{4}$ due to oxidative stress-mediated oxidation (e.g. by peroxynitrite) [1, 12]. Importantly, betulinic acid also reduces the expression of NADPH oxidases (NOX4 and p22phox) [62], a major source of ROS in the vasculature [71]. We have demonstrated that betulic acid reduces the levels of peroxynitrite in the mouse in vivo [72]. These results suggest the potential of betulinic acid to reverse eNOS uncoupling. In a mouse stroke model, betulinic acid upregulates eNOS and downregulated NADPH oxidases, events which are associated with a reduction in infarct size [72].

Our recent results indicate that betulinic acid not only enhances eNOS expression but also enhances eNOS enzymatic activity. Treatment of human endothelial cells with betulinic acid leads to phosphorylation of eNOS at serine 1177 and dephosphorylation of eNOS at threonine 495, and an increase in NO production [Hohmann N, Xia N, Forstermann U and $\mathrm{Li} \mathrm{H}$, unpublished data]. This is consistent with a recent report demonstrating that betulinic acid induces an endothelium-dependent, NO-mediated relaxation of isolated rat aorta [73].

\section{Conclusion}

Numerous vasoactive Chinese herbs possess stimulating effects on endothelial NO production, e.g. by enhancing eNOS expression and/or by modulating eNOS phosphorylation status. Such molecular events are likely to be contributing mechanisms for the therapeutic effects of these herbs described in traditional Chinese medicine.

\section{References}

[1] Li H, Forstermann U. Prevention of atherosclerosis by interference with the vascular nitric oxide system. Curr Pharm Des. 2009; 15: 3133-3145.

[2] Li H, Forstermann U. Nitric oxide in the pathogenesis of vascular disease. J Pathol. 2000; 190: 244-254.

[3] Csiszar A, Labinskyy N, Pinto JT, Ballabh P, Zhang H, Losonczy G, Pearson K, de Cabo R, Pacher P, Zhang C, Ungvari Z. Resveratrol induces mitochondrial biogenesis in endothelial cells. Am J Physiol Heart Circ Physiol. 2009; 297: H13-20.

[4] Nisoli E, Tonello C, Cardile A, Cozzi V, Bracale R, Tedesco L, Falcone S, Valerio A, Cantoni O, Clementi E, Moncada S, Carruba MO. Calorie restriction promotes mitochondrial biogenesis by inducing the expression of eNOS. Science. 2005; 310: 314-317.

[5] Li H, Wallerath T, Munzel T, Forstermann U. Regulation of endothelial-type NO synthase expression in pathophysiology and in response to drugs. Nitric Oxide. 2002; 7: 149-164.

[6] Li H, Wallerath T, Forstermann U. Physiological mechanisms regulating the expression of endothelial-type NO synthase. Nitric Oxide. 2002; 7: 132-147.

[7] Fleming I. Molecular mechanisms underlying the activation of eNOS. Pflugers Arch. 2010; 459: 793-806.

[8] Mattagajasingh I, Kim CS, Naqvi A, Yamamori T, Hoffman TA, Jung SB, DeRicco J, Kasuno K, Irani K. SIRT1 promotes endothelium-dependent vascular relaxation by 
activating endothelial nitric oxide synthase. Proc Natl Acad Sci USA. 2007; 104: 14855-14860.

[9] Maas R, Boger R, Luneburg N. ADMA and the role of the genes: lessons from genetically modified animals and human gene polymorphisms. Pharmacol Res. 2009; 60: 475480.

[10] Pope AJ, Karuppiah K, Cardounel AJ. Role of the PRMT-DDAH-ADMA axis in the regulation of endothelial nitric oxide production. Pharmacol Res. 2009; 60: 461-465.

[11] Forstermann U, Li H. Therapeutic effect of enhancing endothelial nitric oxide synthase (eNOS) expression and preventing eNOS uncoupling. Br J Pharmacol. 2010: DOI: 10.1111/j.1476-5381.2010.01196.x.

[12] Forstermann U, Munzel T. Endothelial nitric oxide synthase in vascular disease: from marvel to menace. Circulation. 2006; 113: 1708-1714.

[13] Xia N, Daiber A, Habermeier A, Closs EI, Thum T, Spanier G, Lu Q, Oelze M, Torzewski M, Lackner KJ, Münzel T, Förstermann U, Li H. Resveratrol reverses endothelial nitric-oxide synthase uncoupling in apolipoprotein E knockout mice. J Pharmacol Exp Ther. 2010; 335: 149-154.

[14] Edgell CJ, McDonald CC, Graham JB. Permanent cell line expressing human factor VIIIrelated antigen established by hybridization. Proc Natl Acad Sci USA. 1983; 80: 37343737.

[15] Li H, Oehrlein SA, Wallerath T, Ihrig-Biedert I, Wohlfart P, Ulshofer T, Jessen T, Herget $\mathrm{T}$, Forstermann $\mathrm{U}$, Kleinert $\mathrm{H}$. Activation of protein kinase $\mathrm{C}$ alpha and/or epsilon enhances transcription of the human endothelial nitric oxide synthase gene. Mol Pharmacol. 1998; 53: 630-637.

[16] Xia N, Bollinger L, Steinkamp-Fenske K, Forstermann U, Li H. Prunella vulgaris L. Upregulates eNOS expression in human endothelial cells. Am J Chin Med. 2010; 38: 599-611.

[17] Zhang Y, Hu G, Lin HC, Hong SJ, Deng YH, Tang JY, Seto SW, Kwan YW, Waye MM, Wang YT, Lee SM. Radix Astragali extract promotes angiogenesis involving vascular endothelial growth factor receptor-related phosphatidylinositol 3kinase/Akt-dependent pathway in human endothelial cells. Phytother Res. 2009; 23: 1205-1213.

[18] Wohlfart P, Xu H, Endlich A, Habermeier A, Closs EI, Hubschle T, Mang C, Strobel H, Suzuki T, Kleinert H, Forstermann U, Ruetten H, Li H. Antiatherosclerotic effects of small-molecular-weight compounds enhancing endothelial nitric-oxide synthase (eNOS) expression and preventing eNOS uncoupling. J Pharmacol Exp Ther. 2008; 325: 370-379.

[19] Huang KC. The pharmacology of Chinese herbs. Second edition ed. Boca Raton: CRC Press; 1999.

[20] Sun H, Yuan B, Liu B, Zhang C. The effect of Prunella vulgaris L. extracts on isolated rabbit artery. Xi'an Jiao Tong Da Xue Xue Bao. 2005; 26: 19-21.

[21] Wang HB, Zhang ZY, Su ZW, Li CG. [The effect of total saponins from common selfheal (Prunella vulgaris) on experimental myocardial infarction and hypertension of anesthetized rats]. Zhong Cao Yao. 1994; 25: 264-266.

[22] Heart-Disease-Group. [Clinical observation with Jiangya-Jiangzhi-chongii]. Zhonghua Xin Xue Guan Bing Za Zhi. 1976; 16: 54-56. 
[23] Liu Y, Song S-J, Xu S-X. [Advances in the study on the chemical constituents and biological activities of Prunella vulgaris L.]. Journal of Shenyang Pharmaceutical University. 2003; 20: 55-59.

[24] Steinkamp-Fenske K, Bollinger L, Voller N, Xu H, Yao Y, Bauer R, Forstermann U, Li H. Ursolic acid from the Chinese herb danshen (Salvia miltiorrhiza L.) upregulates eNOS and downregulates Nox4 expression in human endothelial cells. Atherosclerosis. 2007; 195: e104-111.

[25] Li H, Xia N, Brausch I, Yao Y, Forstermann U. Flavonoids from artichoke (Cynara scolymus L.) up-regulate endothelial-type nitric-oxide synthase gene expression in human endothelial cells. J Pharmacol Exp Ther. 2004; 310: 926-932.

[26] Zhou L, Zuo Z, Chow MS. Danshen: an overview of its chemistry, pharmacology, pharmacokinetics, and clinical use. J Clin Pharmacol. 2005; 45: 1345-1359.

[27] Wang G, Wang L, Xiong ZY, Mao B, Li TQ. Compound salvia pellet, a traditional Chinese medicine, for the treatment of chronic stable angina pectoris compared with nitrates: a meta-analysis. Med Sci Monit. 2006; 12: SR1-7.

[28] Zhang JH, Shang HC, Gao XM, Zhang BL, Xiang YZ, Cao HB, Ren M, Wang H. Compound Salvia droplet pill, a traditional Chinese medicine, for the treatment of unstable angina pectoris: a systematic review. Med Sci Monit. 2008; 14: RA1-7.

[29] Lam FF, Yeung JH, Cheung JH. Mechanisms of the dilator action of Danshen (Salvia miltiorrhiza) on rat isolated femoral artery. J Cardiovasc Pharmacol. 2005; 46: 361-368.

[30] Lei XL, Chiou GC. Studies on cardiovascular actions of Salvia miltiorrhiza. Am J Chin Med. 1986; 14: 26-32.

[31] Ji X, Tan BK, Zhu YC, Linz W, Zhu YZ. Comparison of cardioprotective effects using ramipril and DanShen for the treatment of acute myocardial infarction in rats. Life Sci. 2003; 73: 1413-1426.

[32] Wu TW, Zeng LH, Fung KP, Wu J, Pang H, Grey AA, Weisel RD, Wang JY. Effect of sodium tanshinone IIA sulfonate in the rabbit myocardium and on human cardiomyocytes and vascular endothelial cells. Biochem Pharmacol. 1993; 46: 23272332.

[33] Wang Z, Roberts JM, Grant PG, Colman RW, Schreiber AD. The effect of a medicinal Chinese herb on platelet function. Thromb Haemost. 1982; 48: 301-306.

[34] Chen YH, Lin SJ, Ku HH, Shiao MS, Lin FY, Chen JW, Chen YL. Salvianolic acid B attenuates VCAM-1 and ICAM-1 expression in TNF-alpha-treated human aortic endothelial cells. J Cell Biochem. 2001; 82: 512-521.

[35] Chen YL, Yang SP, Shiao MS, Chen JW, Lin SJ. Salvia miltiorrhiza inhibits intimal hyperplasia and monocyte chemotactic protein-1 expression after balloon injury in cholesterol-fed rabbits. J Cell Biochem. 2001; 83: 484-493.

[36] Wu YJ, Hong CY, Lin SJ, Wu P, Shiao MS. Increase of vitamin E content in LDL and reduction of atherosclerosis in cholesterol-fed rabbits by a water-soluble antioxidant-rich fraction of Salvia miltiorrhiza. Arterioscler Thromb Vasc Biol. 1998; 18: 481-486.

[37] Wang X, Morris-Natschke SL, Lee KH. New developments in the chemistry and biology of the bioactive constituents of Tanshen. Med Res Rev. 2007; 27: 133-148.

[38] Kong DY. Chemical constituents of Salvia miltiorrhiza. Zhongguo Yiyao Gongye Zazhi. 1989; 20: 279-285. 
[39] Jager S, Trojan H, Kopp T, Laszczyk MN, Scheffler A. Pentacyclic triterpene distribution in various plants - rich sources for a new group of multi-potent plant extracts. Molecules. 2009; 14: 2016-2031.

[40] Sultana N. Clinically useful anticancer, antitumor, and antiwrinkle agent, ursolic acid and related derivatives as medicinally important natural product. J Enzyme Inhib Med Chem. 2011.

[41] Shao JW, Dai YC, Xue JP, Wang JC, Lin FP, Guo YH. In vitro and in vivo anticancer activity evaluation of ursolic acid derivatives. Eur J Med Chem. 2011; 46: 2652-2661.

[42] Kim J, Jang DS, Kim H, Kim JS. Anti-lipase and lipolytic activities of ursolic acid isolated from the roots of Actinidia arguta. Arch Pharm Res. 2009; 32: 983-987.

[43] Rao VS, Melo CL, Queiroz MG, Lemos TL, Menezes DB, Melo TS, Santos FA. Ursolic acid, a pentacyclic triterpene from Sambucus australis, prevents abdominal adiposity in mice fed a high-fat diet. J Med Food. 2011; in press. doi:10.1089/jmf.2010.0267.

[44] Jang SM, Yee ST, Choi J, Choi MS, Do GM, Jeon SM, Yeo J, Kim MJ, Seo KI, Lee MK. Ursolic acid enhances the cellular immune system and pancreatic beta-cell function in streptozotocin-induced diabetic mice fed a high-fat diet. Int Immunopharmacol. 2009; 9: 113-119.

[45] Jayaprakasam B, Olson LK, Schutzki RE, Tai MH, Nair MG. Amelioration of obesity and glucose intolerance in high-fat-fed C57BL/ 6 mice by anthocyanins and ursolic acid in Cornelian cherry (Cornus mas). J Agric Food Chem. 2006; 54: 243-248.

[46] Jang SM, Kim MJ, Choi MS, Kwon EY, Lee MK. Inhibitory effects of ursolic acid on hepatic polyol pathway and glucose production in streptozotocin-induced diabetic mice. Metabolism. 2010; 59: 512-519.

[47] Zhou Y, Li JS, Zhang X, Wu YJ, Huang K, Zheng L. Ursolic acid inhibits early lesions of diabetic nephropathy. Int J Mol Med. 2010; 26: 565-570.

[48] Wang ZH, Hsu CC, Huang CN, Yin MC. Anti-glycative effects of oleanolic acid and ursolic acid in kidney of diabetic mice. Eur J Pharmacol. 2010; 628: 255-260.

[49] Somova LO, Nadar A, Rammanan P, Shode FO. Cardiovascular, antihyperlipidemic and antioxidant effects of oleanolic and ursolic acids in experimental hypertension. Phytomedicine. 2003; 10: 115-121.

[50] Takada K, Nakane T, Masuda K, Ishii H. Ursolic acid and oleanolic acid, members of pentacyclic triterpenoid acids, suppress TNF-alpha-induced E-selectin expression by cultured umbilical vein endothelial cells. Phytomedicine. 2010; 17: 1114-1119.

[51] Pozo M, Castilla V, Gutierrez C, de Nicolas R, Egido J, Gonzalez-Cabrero J. Ursolic acid inhibits neointima formation in the rat carotid artery injury model. Atherosclerosis. 2006; 184: 53-62.

[52] Messner B, Zeller I, Ploner C, Frotschnig S, Ringer T, Steinacher-Nigisch A, Ritsch A, Laufer G, Huck C, Bernhard D. Ursolic acid causes DNA-damage, p53-mediated, mitochondria- and caspase-dependent human endothelial cell apoptosis, and accelerates atherosclerotic plaque formation in vivo. Atherosclerosis. 2011: doi:10.1016/j.atherosclerosis.2011.1005.1025.

[53] Lee AW, Chen TL, Shih CM, Huang CY, Tsao NW, Chang NC, Chen YH, Fong TH, Lin FY. Ursolic acid induces allograft inflammatory factor-1 expression via a nitric oxide-related mechanism and increases neovascularization. J Agric Food Chem. 2010; 58: 12941-12949. 
[54] Aguirre-Crespo F, Vergara-Galicia J, Villalobos-Molina R, Javier Lopez-Guerrero J, Navarrete-Vazquez G, Estrada-Soto S. Ursolic acid mediates the vasorelaxant activity of Lepechinia caulescens via NO release in isolated rat thoracic aorta. Life Sci. 2006; 79: 1062-1068.

[55] Xu H, Goettsch C, Xia N, Horke S, Morawietz H, Forstermann U, Li H. Differential roles of PKCalpha and PKCepsilon in controlling the gene expression of Nox4 in human endothelial cells. Free Radic Biol Med. 2008; 44: 1656-1667.

[56] Chen XJ, Yu CL, Liu JF. [Protective effects of total saponins of semen Ziziphi spinosae on cultured rat myocardial cells]. Zhongguo Yao Li Xue Bao. 1990; 11: 153-155.

[57] Wan HY, Ding L, Kong XP, Liu SJ, Chen XJ. [Effect of total saponins of semen Ziziphi spinosae on hypoxia-reoxygenation injury in myocardial cells]. Zhongguo Bingli Shengli Za Zhi. 1997; 13: 522-526.

[58] Gu WX, Liu JF, Zhang JX, Liu XM, Liu JS, Chen YR. [Blood pressure-lowering effect and mechanism of total saponins from Ziziphus Mill seeds]. Di Yi Jun Yi Da Xue Xue Bao. 1987; 7: 8-10.

[59] Zhang D, Yuang BX, Sun H. [The effect of jujuboside on rats with spontaneous hypertension]. Xi'an Jiao Tong Da Xue Xue Bao. 2003; 24: 59-60.

[60] Wu SX, Lang XC, Jia BY, Zhao SX, Li MX, Lan MY. [Effects of Ziziphus spinosa Hu on serum lipoprotein and experimental atherosclerosis]. Zhongguo Zhong Yao Za Zhi. 1989; 14: 434-451, 448.

[61] Wang X, Xie M. [Effects of suanzaoren decoction on serum NO and the Level of cytokines in rats]. Beijing Zhong Yi Yao Da Xue Xue Bao. 2004; 11: 16-18.

[62] Steinkamp-Fenske K, Bollinger L, Xu H, Yao Y, Horke S, Forstermann U, Li H. Reciprocal regulation of endothelial nitric-oxide synthase and NADPH oxidase by betulinic acid in human endothelial cells. J Pharmacol Exp Ther. 2007; 322: 836-842.

[63] Li L-M, Liao X, Peng S-L, Ding L-S. Chemical constituents from the seeds of Ziziphus jujuba var. spinosa (Bunge) Hu. Journal of Integrative Plant Biology. 2005; 47: 494-498.

[64] Zhao J, Li SP, Yang FQ, Li P, Wang YT. Simultaneous determination of saponins and fatty acids in Ziziphus jujuba (Suanzaoren) by high performance liquid chromatography-evaporative light scattering detection and pressurized liquid extraction. J Chromatogr A. 2006; 1108: 188-194.

[65] Zhang M, Zhang Y, Xie J. Simultaneous determination of jujuboside A, B and betulinic acid in semen Ziziphi spinosae by high performance liquid chromatographyevaporative light scattering detection. J Pharm Biomed Anal. 2008; 48: 1467-1470.

[66] Mullauer FB, Kessler JH, Medema JP. Betulinic acid, a natural compound with potent anticancer effects. Anticancer Drugs. 2010; 21: 215-227.

[67] Fulda S. Betulinic acid: a natural product with anticancer activity. Mol Nutr Food Res. 2009; 53: 140-146.

[68] Eksioglu-Demiralp E, Kardas ER, Ozgul S, Yagci T, Bilgin H, Sehirli O, Ercan F, Sener G. Betulinic acid protects against ischemia/reperfusion-induced renal damage and inhibits leukocyte apoptosis. Phytother Res. 2010; 24: 325-332.

[69] Genet C, Strehle A, Schmidt C, Boudjelal G, Lobstein A, Schoonjans K, Souchet M, Auwerx J, Saladin R, Wagner A. Structure-activity relationship study of betulinic acid, a novel and selective TGR5 agonist, and its synthetic derivatives: potential impact in diabetes. J Med Chem. 2010; 53: 178-190. 
[70] Yoon JJ, Lee YJ, Kim JS, Kang DG, Lee HS. Protective role of betulinic acid on TNFalpha-induced cell adhesion molecules in vascular endothelial cells. Biochem Biophys Res Commun. 2010; 391: 96-101.

[71] Forstermann U. Oxidative stress in vascular disease: causes, defense mechanisms and potential therapies. Nat Clin Pract Cardiovasc Med. 2008; 5: 338-349.

[72] Lu Q, Xia N, Xu H, Guo L, Wenzel P, Daiber A, Munzel T, Forstermann U, Li H. Betulinic acid protects against cerebral ischemia-reperfusion injury in mice by reducing oxidative and nitrosative stress. Nitric Oxide. 2011; 24: 132-138.

[73] Fu JY, Xia ML, Lu JF, Liu Q, Cai X, Yang J, Wang HP, Xia Q. [Betulinic acid ameliorates impairment of endothelium-dependent relaxation induced by oxidative stress in rat aorta]. Zhejiang Da Xue Xue Bao Yi Xue Ban. 2010; 39: 523-529.

[74] Xu HB, Huang ZQ. Vasorelaxant effects of icariin on isolated canine coronary artery. J Cardiovasc Pharmacol. 2007; 49: 207-213.

[75] Yi XQ, Li T, Wang JR, Wong VK, Luo P, Wong IY, Jiang ZH, Liu L, Zhou H. Total ginsenosides increase coronary perfusion flow in isolated rat hearts through activation of PI3K/ Akt-eNOS signaling. Phytomedicine. 2010; 17: 1006-1015.

[76] Jeon BH, Kim CS, Kim HS, Park JB, Nam KY, Chang SJ. Effect of Korean red ginseng on blood pressure and nitric oxide production. Acta Pharmacol Sin. 2000; 21: 1095-1100.

[77] Ou HC, Chou FP, Lin TM, Yang CH, Sheu WH. Protective effects of honokiol against oxidized LDL-induced cytotoxicity and adhesion molecule expression in endothelial cells. Chem Biol Interact. 2006; 161: 1-13.

[78] Hong SJ, Wan JB, Zhang Y, Hu G, Lin HC, Seto SW, Kwan YW, Lin ZX, Wang YT, Lee $\mathrm{SM}$. Angiogenic effect of saponin extract from Panax notoginseng on HUVECs in vitro and zebrafish in vivo. Phytother Res. 2009; 23: 677-686.

[79] Zhang W, Xu XL, Wang YQ, Wang CH, Zhu WZ. Effects of 2,3,4',5-tetrahydroxystilbene 2-O-beta-D-glucoside on vascular endothelial dysfunction in atherogenic-diet rats. Planta Med. 2009; 75: 1209-1214.

[80] Yan LP, Chan SW, Chan AS, Chen SL, Ma XJ, Xu HX. Puerarin decreases serum total cholesterol and enhances thoracic aorta endothelial nitric oxide synthase expression in diet-induced hypercholesterolemic rats. Life Sci. 2006; 79: 324-330.

[81] Zhou Z, Wang SQ, Liu Y, Miao AD. Cryptotanshinone inhibits endothelin-1 expression and stimulates nitric oxide production in human vascular endothelial cells. Biochim Biophys Acta. 2006; 1760: 1-9.

[82] Kim SH, Choi M, Lee Y, Kim YO, Ahn DS, Kim YH, Kang ES, Lee EJ, Jung M, Cho JW, Williams DR, Lee HC. Natural therapeutic magnesium lithospermate B potently protects the endothelium from hyperglycaemia-induced dysfunction. Cardiovasc Res. 2010; 87: 713-722.

[83] Chan P, Liu JC, Lin LJ, Chen PY, Cheng TH, Lin JG, Hong HJ. Tanshinone IIA inhibits angiotensin II-induced cell proliferation in rat cardiac fibroblasts. Am J Chin Med. 2011; 39: 381-394.

[84] Kim DD, Sanchez FA, Duran RG, Kanetaka T, Duran WN. Endothelial nitric oxide synthase is a molecular vascular target for the Chinese herb Danshen in hypertension. Am J Physiol Heart Circ Physiol. 2007; 292: H2131-H2137.

[85] Chen Y, Ruan Y, Li L, Chu Y, Xu X, Wang Q, Zhou X. Effects of Salvia miltiorrhiza extracts on rat hypoxic pulmonary hypertension, heme oxygenase-1 and nitric oxide synthase. Chin Med J (Engl). 2003; 116: 757-760. 
[86] Bao M, Lou Y. Flavonoids from seabuckthorn protect endothelial cells (EA.hy926) from oxidized low-density lipoprotein induced injuries via regulation of LOX-1 and eNOS expression. J Cardiovasc Pharmacol. 2006; 48: 834-841.

[87] Suo Z, Liu Y, Ferreri M, Zhang T, Liu Z, Mu X, Han B. Impact of matrine on inflammation related factors in rat intestinal microvascular endothelial cells. $J$ Ethnopharmacol. 2009; 125: 404-409.

[88] Shao Z, Li J, Zhao Z, Gao C, Sun Z, Liu X. Effects of tetramethylpyrazine on nitric oxide/cGMP signaling after cerebral vasospasm in rabbits. Brain Res. 2010; 1361: 67-75.

[89] Jin SN, Wen JF, Kim HY, Kang DG, Lee HS, Cho KW. Vascular relaxation by ethanol extract of Xanthoceras sorbifolia via Akt- and SOCE-eNOS-cGMP pathways. $J$ Ethnopharmacol. 2010; 132: 240-245.

[90] Meng L, Qu L, Tang J, Cai SQ, Wang H, Li X. A combination of Chinese herbs, Astragalus membranaceus var. mongholicus and Angelica sinensis, enhanced nitric oxide production in obstructed rat kidney. Vascul Pharmacol. 2007; 47: 174-183.

[91] Hou YZ, Zhao GR, Yang J, Yuan YJ, Zhu GG, Hiltunen R. Protective effect of Ligusticum chuanxiong and Angelica sinensis on endothelial cell damage induced by hydrogen peroxide. Life Sci. 2004; 75: 1775-1786.

[92] Kang Y, Hu M, Zhu Y, Gao X, Wang MW. Antioxidative effect of the herbal remedy Qin Huo Yi Hao and its active component tetramethylpyrazine on high glucose-treated endothelial cells. Life Sci. 2009; 84: 428-436.

[93] Hua Q, Zhu X, Li P, Tang H, Cai D, Xu Y, Jia X, Chen J, Shen Y. Refined Qing Kai Ling, traditional Chinese medicinal preparation, reduces ischemic stroke-induced infarct size and neurological deficits and increases expression of endothelial nitric oxide synthase. Biol Pharm Bull. 2008; 31: 633-637.

[94] Wu Y, Xia ZY, Meng QT, Zhu J, Lei S, Xu J, Dou J. Shen-Fu injection preconditioning inhibits myocardial ischemia-reperfusion injury in diabetic rats: activation of eNOS via the PI3K/Akt pathway. J Biomed Biotechnol. 2011; 2011: 384627.

[95] Liang JQ, Wu K, Jia ZH, Liu C, Ding J, Huang SN, Yin PP, Wu XC, Wei C, Wu YL, Wang HY. Chinese medicine Tongxinluo modulates vascular endothelial function by inducing eNOS expression via the PI-3K/Akt/HIF-dependent signaling pathway. J Ethnopharmacol. 2011; 133: 517-523.

[96] Li XD, Yang YJ, Geng YJ, Jin C, Hu FH, Zhao JL, Zhang HT, Cheng YT, Qian HY, Wang $\mathrm{LL}$, Zhang BJ, $\mathrm{Wu}$ YL. Tongxinluo reduces myocardial no-reflow and ischemiareperfusion injury by stimulating the phosphorylation of eNOS via the PKA pathway. Am J Physiol Heart Circ Physiol. 2010; 299: H1255-1261. 


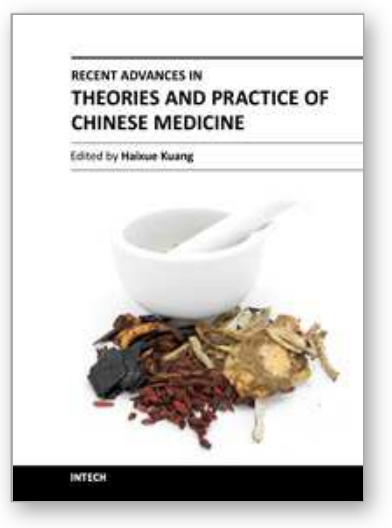

\author{
Recent Advances in Theories and Practice of Chinese Medicine \\ Edited by Prof. Haixue Kuang
}

ISBN 978-953-307-903-5

Hard cover, 504 pages

Publisher InTech

Published online 18, January, 2012

Published in print edition January, 2012

During the recent years, traditional Chinese medicine (TCM) has attracted the attention of researchers all over the world. It is looked upon not only as a bright pearl, but also a treasure house of ancient Chinese culture. Nowadays, TCM has become a subject area with high potential and the possibility for original innovation. This book titled Recent Advances in Theories and Practice of Chinese Medicine provides an authoritative and cutting-edge insight into TCM research, including its basic theories, diagnostic approach, current clinical applications, latest advances, and more. It discusses many often neglected important issues, such as the theory of TCM property, and how to carry out TCM research in the direction of TCM property theory using modern scientific technology. The authors of this book comprise an international group of recognized researchers who possess abundant clinical knowledge and research background due to their years of practicing TCM. Hopefully, this book will help our readers gain a deeper understanding of the unique characteristics of Chinese medicine.

\title{
How to reference
}

In order to correctly reference this scholarly work, feel free to copy and paste the following:

Huige Li (2012). Effects of Vasoactive Chinese Herbs on the Endothelial NO System, Recent Advances in Theories and Practice of Chinese Medicine, Prof. Haixue Kuang (Ed.), ISBN: 978-953-307-903-5, InTech, Available from: http://www.intechopen.com/books/recent-advances-in-theories-and-practice-of-chinesemedicine/effects-of-vasoactive-chinese-herbs-on-the-endothelial-no-system

\section{INTECH}

open science | open minds

\section{InTech Europe}

University Campus STeP Ri

Slavka Krautzeka 83/A

51000 Rijeka, Croatia

Phone: +385 (51) 770447

Fax: +385 (51) 686166

www.intechopen.com

\section{InTech China}

Unit 405, Office Block, Hotel Equatorial Shanghai

No.65, Yan An Road (West), Shanghai, 200040, China

中国上海市延安西路65号上海国际贵都大饭店办公楼 405 单元

Phone: +86-21-62489820

Fax: $+86-21-62489821$ 
(C) 2012 The Author(s). Licensee IntechOpen. This is an open access article distributed under the terms of the Creative Commons Attribution 3.0 License, which permits unrestricted use, distribution, and reproduction in any medium, provided the original work is properly cited. 